See discussions, stats, and author profiles for this publication at: https://www.researchgate.net/publication/333692399

\title{
Assessment of Concrete Durability in Buildings: the Effects of the Quality of Cements Available in Lagos, Nigeria
}

Article $\cdot$ March 2019

Dol: 10.15866/irece.v10i2.15575

\section{CITATIONS}

5 authors, including:

Opeyemi Joshua

Covenant University Ota Ogun State, Nigeria

58 PUBLICATIONS 166 CITATIONS

SEE PROFILE

Ayodeji Ogunde

Covenant University Ota Ogun State, Nigeria

44 PUBLICATIONS 188 CITATIONS

SEE PROFILE

Some of the authors of this publication are also working on these related projects:

Sustainable development, Energy conservation View project

Concrete and Concrete Materials View project
READS

97

Olabosipo I. Fagbenle

Covenant University Ota Ogun State, Nigeria

33 PUBLICATIONS 161 CITATIONS

SEE PROFILE

David Nduka

Covenant University Ota Ogun State, Nigeria

28 PUBLICATIONS 76 CITATIONS

SEE PROFILE 


\title{
Assessment of Concrete Durability in Buildings: the Effects of the Quality of Cements Available in Lagos, Nigeria
}

\author{
Opeyemi Joshua $^{1}$, Kolapo O. Olusola ${ }^{2}$, Olabosipo I. Fagbenle ${ }^{1}$, \\ Ayodeji O. Ogunde ${ }^{1}$, David O. Nduka ${ }^{1}$
}

\begin{abstract}
This paper presents an investigative research that aims to find the effects of the cements available in Lagos, Nigeria on the durability of concrete within the study area. This is in an attempt to stem the rate of building failures in Lagos, Nigeria. The physical, the mechanical and the microstructural properties of the cements have been determined and compared with the standard properties as specified in relevant standards. $150 \mathrm{~mm}$ cubes have been cast with these cements and all the sources of aggregates within the study area. Laboratory findings have discovered that all the cements investigated have fallen short of the expected strengths specified in standards but the labelled brands had values close to the strength standards but the unlabeled ones have fallen far short of the standard strength. The chemical analysis has complied with standard requirements except for their loss on ignition (LOI) values and the chemical properties have been complemented by the microstructural morphology as determined with the Scanning Electron Microscope (SEM) though the unlabeled brands have tendencies for alkali silica reactivity due to higher levels of alkali present in them. In assessing their performance in concrete, the concrete cube strength has met the expected 20MPa except for the unlabeled brands that have fallen a little short of it. The effects of these cements have been discovered to be very significant on the concrete durability within the study area. It is thereby recommended that the Nigerian regulatory agencies on cements make more efforts in order to ensure that cement manufacturers in Nigeria improve the quality of their cement brands in order to standard strength specification. All cements should be temporarily used as a 32.5 strength class, despising the labelled 42.5, pending when the manufacturers would fully comply their products to standard. Copyright () 2019 Praise Worthy Prize S.r.l. - All rights reserved.
\end{abstract}

Keywords: Cement, Reinforced Concrete, Concrete Strength, Concrete Durability and Cement Strength-Class

$\mathrm{A} / \mathrm{F}$

$\mathrm{Al}_{2} \mathrm{O}_{3}$

ANOVA

AR

ASR

$\mathrm{C} / \mathrm{S}$

$\mathrm{C}_{2} \mathrm{~S}$

$\mathrm{C}_{3} \mathrm{~A}$

$\mathrm{C}_{3} \mathrm{~S}$

$\mathrm{C}_{4} \mathrm{AF}$

$\mathrm{CaO}$

$\mathrm{Fe}_{2} \mathrm{O}_{3}$

IR

$\mathrm{K}_{2} \mathrm{O}$

LOI

LSF

$\mathrm{MgO}$

$\mathrm{Na}_{2} \mathrm{O}$

SEM

$\mathrm{SiO}_{2}$
$\mathrm{SO}_{3}$

$\mathrm{SON}$

SR

Alumina to Ferrite ratio

Aluminum Oxide

Analysis of variance

Alumina Ratio

Alkaline Silica Reaction

Calcium to Silica ratio

Dicalcium Silicate

Tricalcium Aluminate

Tricalcium Silicate

Tetra calcium Alumino Ferrate

Calcium oxide

Iron trioxide

Insoluble Residue

Potassium oxide

Loss on ignition

Lime Saturation Factor

Magnesium oxide

Sodium Oxide

Scanning Electron Microscope

Silica dioxide

\author{
Sulphur Trioxide \\ Standard Organization of Nigeria \\ Silica ratio \\ X-Ray Fluorescence
}

\section{Introduction}

This study is more of a forensic investigative work in an attempt to curb and to prevent building failures in Lagos Nigeria that has resulted to economic losses, worsening the existing housing deficit and unimaginable casualties to life and properties as highlighted in [1]. A building has been defined as an enclosure equipped with at least the basic essential internal comfort facilities intended for human use [2]. Such enclosures range from simple bungalows to multi-storey buildings with several levels of suspended floors. A building can be divided into two main broad components, namely, the structural components which bear the whole weight of the building and effectively transmit it to the ground, for example, slabs, beams, columns and foundation; and non-structural 
components that simply bear its own weight and transmit its weight to the structural components. Instance of the latter include partition walls, electrical and mechanical installations, windows and doors among others. The primary supporting structure, that is, the structural elements of a building can be made of different materials: the most common ones are reinforced concrete, steel, and timber. However, the use of reinforced concrete is the most prominent [1]-[25].

[3], [4] have deduced that over $90 \%$ of storey buildings in Nigeria have been made from reinforced concrete, hence, the study of then used concrete is significant to the quality of Nigerian's buildings. Studies also show the effects and low level of awareness of the applications of cement strength class in concrete produced in Nigeria [5]. Generally, buildings will not collapse until the structural components fail or begin to fail. Since the vast majority of the structural building components in Nigeria are made of concrete, it can be deduced that the greatest percentage of building structural failures is the result of concrete failure. This concrete failure could happen because of the production of lower concrete quality below the capacity to effectively resist its imposed load; service factors that deteriorate a good concrete to a quality decrease below the service requirement like the ingress of nitrates in concrete service conditions [6]; and when the concrete structure is loaded beyond its service limits like in upward building adaptation. As inferred from [7] and [8], about twenty six percent $(26 \%)$ of building failures has been attributed to the use of substandard building materials. The strength of reinforced concrete is a function of the suitability and the quality of its constituent materials, that is, the higher the quality of these constituent materials is, the better the reinforced concrete produced with them is. These constituent materials play a major role in the strength and other properties of the resulting reinforced concrete. The major constituents of reinforced concrete material are cement, aggregates (fine and coarse), steel reinforcement and water. This study assesses the effects of the cements available in Lagos, Nigeria's market on the durability of concrete used in buildings. This is based on the premise that other factors in concrete production are of good standard with the cement being the only variable.

This study is experimental, and the methods of data collected have come from relevant standard laboratory procedure. The setting-times, the strength, the composition and the microstructure of the cements have been determined. ANOVA has been used in order to analyze for the significant concrete-strength variable due to material. Conclusions and recommendations have been then drawn from the discussed results.

\section{Materials and Methods}

\section{II.1. Materials}

The materials that would be used in this study include the cements, which would be by the various brands available in the Lagos State market, and they include Dangote $42.5 \mathrm{~N}$ and $42.5 \mathrm{R}$ strength classes, Larfarge or Elephant 32.5, Eagle and Ibeto brands had no label of the strength class. The fine aggregates used in this study are quarry fines (grounded crushed stones), burrow pit sharp sand and river dredged sand all from five sources to represent all sources of fine aggregates used in Lagos State. The fine aggregates have been washed of all impurities and aired in the sun for a week in order to obtain an air-dry water content condition, and then they have been sieved with the \#4 $(4.75 \mathrm{~mm})$ in order to ensure its conformance to fine aggregates to be used in concrete production as required in [9]. Part of one of the prepared river dredged sand has been further sieved in a stack of $\# 10$, \#18, \#30, \#50, \#100 and \#200 (2mm, 1mm, 0.6mm, $0.3 \mathrm{~mm}, 0.15 \mathrm{~mm}$ and $75 \mu \mathrm{m}$ respectively) sieves sizes.

The sand retained in each sieve has been then mixed in proportions in order to simulate the sand used for the determination of the strength of cement as specified in [10]. The coarse aggregates used for the cement production have been $19 \mathrm{~mm}$ size quarry crushed aggregate washed free of fines and sun-dried for a week in order to obtain an air-dried water content condition.

They have also been obtained from five sources in order to represent all the sources of coarse aggregates used in concrete production in Lagos state. Borehole water has been used in all cases that could pass for a drinking water.

\section{II.2. Methods}

The method employed in this study has been to determine the macro and the micro properties of the different cement being investigated and to compare these properties with standard ones as specified in [11] and [12]. The properties to be determined are the setting times performed in accordance to [13], the determination of the strength of cement done in accordance to [10], the oxide composition determined by X-Ray Fluorescence (XRF) and the morphological analysis using the Scanning Electron Microscope (SEM). 150mm standardized prescribed concrete that conforms to [14], [15] and [16] has been prepared and cured for twentyeight days. The mix design has been a standardized mix ST-4 (330kg cement to $1835 \mathrm{~kg}$ total aggregate with fine aggregates being between $35 \%-45 \%$ of the total aggregates and a slump value between $40 \mathrm{~mm}-110 \mathrm{~mm}$ ) which should give a characteristic strength of $20 \mathrm{MPa}$ as specified in [15] and [16]. This implies that a standard target cube strength of greater than $20 \mathrm{MPa}$ is expected.

All the possible combinations of the fine and the coarse aggregates from the five sources have been employed in the casting of the cubes in the prescribed mix ratios with all the cements in this study, making twenty-five fine-coarse combinations in triplicates for each one of the five cements being investigated. Seventyfive cubes have been cast per cement, totalling to three hundred and seventy-five cubes for the five cements being investigated. These concrete cubes represent all the 
possible concrete that could be cast in Lagos state since they have been made from all the sources of fine and coarse aggregates used in Lagos State and combining then with all the cements available in Lagos State, Nigeria. 33.3\% fine aggregate to total aggregate ratio has been employed in this study, resulting to a mix design of 1:2:4, with a $19 \mathrm{~mm}$ aggregate size. The cubes have been cured by total immersion in water for the curing period and the cube strength would be determined afterwards.

\section{Results and Discussions}

The various cement in this study is represented as samples $\mathrm{C} 1$ to $\mathrm{C} 5$ in no specific order.

\section{III.1. Setting Times of Cement}

The results of the setting times are presented in Table I. Both the Nigerian and British standards, [17] and [11] respectively, specify that the initial setting times of 32.5 and 42.5 strength classes should not be less than 60minutes and 75-minutes respectively. As obtained in Table I, all cement brands tested in this study satisfy these requirements.

TABLE I

PASTE OF STANDARD CONSISTENCE AND SETTING TIMES OF CEMENT

\begin{tabular}{cccccc}
\hline \hline $\begin{array}{c}\text { Sample } \\
\text { (Strength } \\
\text { Class) }\end{array}$ & $\begin{array}{c}\text { Water } \\
\text { Pontent of } \\
\text { Paste of } \\
\text { Standard } \\
\text { Consistence } \\
(\%)\end{array}$ & $\begin{array}{c}\text { Initial } \\
\text { Setting } \\
\text { Time } \\
\text { (Mins) }\end{array}$ & $\begin{array}{c}\text { Initial } \\
\text { Setting } \\
\text { Time (To } \\
\text { the Nearest } \\
\text { 5mins) }\end{array}$ & $\begin{array}{c}\text { Final } \\
\text { Setting } \\
\text { Time } \\
\text { (Mins) }\end{array}$ & $\begin{array}{c}\text { Final Setting } \\
\text { Time (To the } \\
\text { Nearest } \\
15 m i n s)\end{array}$ \\
\hline $\mathrm{C} 1^{\mathrm{u}}$ & 38.4 & 215 & 215 & 324 & 330 \\
$\mathrm{C}^{\mathrm{U}}$ & 38.8 & 284 & 285 & 358 & 360 \\
$\mathrm{C} 3(42.5 \mathrm{R})$ & 26.4 & 128 & 130 & 187 & 180 \\
$\mathrm{C} 4(42.5 \mathrm{~N})$ & 28.0 & 148 & 150 & 220 & 225 \\
$\mathrm{C} 5(32.5 \mathrm{~N})$ & 35.2 & 141 & 140 & 201 & 195 \\
Undicates unspecified strength class and other labels on the bag \\
\hline \hline
\end{tabular}

\section{III.2. Mechanical Properties of the Sampled Cement Brands}

From Fig. 1, the cement brands that have performed most in terms of its 28-day cement strength are the brand C3 with strength $39.78 \mathrm{MPa}$ and the C2 with strength 25.21 MPa. None of the cements has satisfied the standard strengths of $42.5 \mathrm{MPa}$ or $32.5 \mathrm{MPa}$ recommended by [11] but $\mathrm{C} 5$ has almost met the 32.5 strength class. C3 and C4 have exceeded the $32.5 \mathrm{MPa}$ strength mark though they have been labeled as 42.5 class. C5 has been the closest one to its labeled mark strength of 32.5 strength class with a strength of 31.3 $\mathrm{MPa}$.

\section{III.3. Chemical Analysis of the Various Brands of Cement}

From Table II, it can be seen that all the oxide compositions are all within limits specified by [18] and [11], except for the percentage of the sum of the alkaline contents for brands $\mathrm{C} 1$ and $\mathrm{C} 2$ which sums up to 1.5 and 1.87 respectively beyond the limits of $0.3-1.3$.

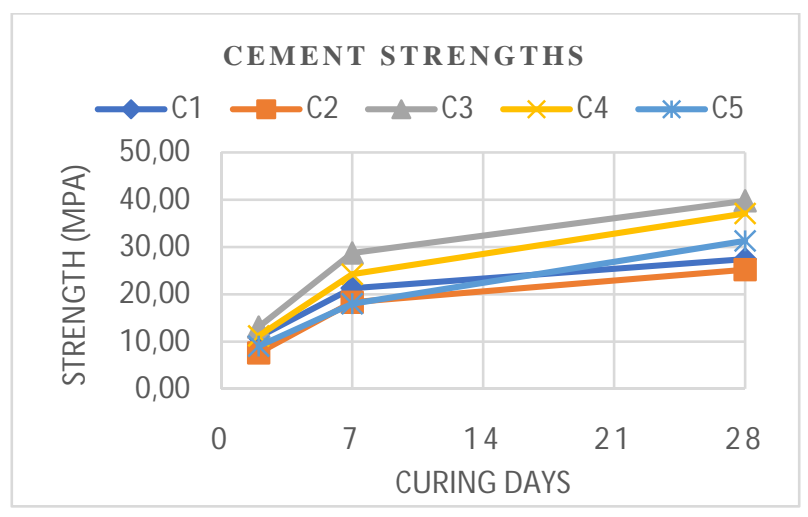

Fig. 1. Compressive Strength of Cement Mortar Cubes at Different Curing Ages

This makes cements $\mathrm{C} 1$ and $\mathrm{C} 2$ more prone to Alkaline Silica Reaction (ASR) and as a result disruptingthe long- term performance of the concrete produced with them by the deleterious disintegrating expansion due to these alkalis [19]. [11] specifies that the sum of $\mathrm{CaO}$ and $\mathrm{SiO}_{2}$, which is mainly responsible for strength, must be greater than $50 \%$ which has been satisfied by all samples. It also specifies that the total percentage of the cement's silicate compositions $\left(\mathrm{C}_{3} \mathrm{~S}+\right.$ $\mathrm{C}_{2} \mathrm{~S}$ ) must be greater than $67 \%$ which has been satisfied by all the samples as the least in this category is the cement brand $\mathrm{C} 1$ totaling to $70.38 \%$. All negative cement compositions could be taken as zero (0) [11]. Bogue's formulae have been used in order to determine all cement's compositions from the oxide compositions.

Table II also shows that the cement compositions comply with limits by [18] and [11] except for the tricalcium silicate $\left(\mathrm{C}_{3} \mathrm{~S}\right)$ and dicalcium silicate $\left(\mathrm{C}_{2} \mathrm{~S}\right)$ of samples $\mathrm{C} 4$ and $\mathrm{C} 5$. The proportion of the $\mathrm{C}_{3} \mathrm{~S}$ is greater than the limits while the one of $\mathrm{C}_{2} \mathrm{~S}$ is somewhat negligible, far below the limits.

These samples, C4 and C5, have showed tendencies of earlier strength but little or no significant long-term strength development [18] and [19]. Generally, values of LOI higher than the acceptable maximum of 5\% limit are expected to affect the strength of the resulting concrete and [18] has showed that an increase in LOI by $1 \%$ can result in $4 \mathrm{MPa}$ decrease in the 28-day strength. LOI can be as a result of $\mathrm{CaCO}_{3}$ that is usually added to clinker before grinding; in which case, it has little effect on the strength. However, all the other sources that could increase LOI especially beyond $5 \%$ could have deleterious effects on the resulting hardened cement.

Samples C3, C4, and C5 exceed the 5\% limit with sample C3 having its LOI value as high as $12.28 \%$. This could be a measure of adulteration of the cement or as a result of post-factory operations such as haulage and storage. In addition, these samples are CEM II(A-L) a indicative of addition of $\mathrm{CaCO}_{3}$ which could cause the elevated LOI. 
TABLE II

RESULTS OF OXIDE AND CEMENT COMPOSITIONS FROM X-RAY FRACTION ANALYSIS AND BASIC RATIOS

\begin{tabular}{|c|c|c|c|c|c|c|c|c|}
\hline \multicolumn{2}{|c|}{ Brand } & C1 & $C 2$ & (C3(42.5R) & (C4(42.5N) & C5(32.5) & Limits & Source of limits \\
\hline \multirow{5}{*}{$\begin{array}{l}\text { Percentage } \\
\text { oxide }\end{array}$} & $\mathrm{SiO}_{2}$ & 19.62 & 20.99 & 21.48 & 17.95 & 19.01 & $17-25$ & (Newman and Cho, 2013)[18] \\
\hline & $\mathrm{Al}_{2} \mathrm{O}_{3}$ & 4.40 & 4.77 & 4.06 & 4.85 & 4.97 & $3-8$ & (Newman and Cho, 2013) [18] \\
\hline & $\mathrm{Fe}_{2} \mathrm{O}_{3}$ & 3.07 & 3.13 & 5.46 & 2.89 & 2.92 & $0.5-6$ & (Newman and Cho, 2013) [18] \\
\hline & $\mathrm{CaO}$ & 61.32 & 62.77 & 62.18 & 61.52 & 64.37 & $60-67$ & (Newman and Cho, 2013) [18] \\
\hline & $\mathrm{MgO}$ & 19.62 & 3.95 & 0.81 & 3.45 & 1.74 & $0.1-4$ & (Newman and Cho, 2013) [18] \\
\hline \multirow[t]{3}{*}{ compositions } & $\mathrm{Na}_{2} \mathrm{O}$ & 0.44 & 0.76 & 0.13 & 0.10 & 0.47 & $<1$ & (Newman and Cho, 2013) [18] \\
\hline & $\mathrm{K}_{2} \mathrm{O}$ & 1.06 & 1.11 & 0.64 & 0.32 & 0.27 & $<1$ & (Newman and Cho, 2013) [18] \\
\hline & $\mathrm{SO}_{3}$ & 3.18 & 2.79 & 2.56 & 1.64 & 2.45 & $\leq 4$ & $\begin{array}{c}\text { (BS EN 197-1, 2011; Newman and Cho, } \\
\text { 2013) }[11,18]\end{array}$ \\
\hline \multicolumn{2}{|c|}{$L O I$} & 2.77 & 3.00 & 12.28 & 7.93 & 5.16 & $0-5$ & $\begin{array}{c}\text { (BS EN 197-1, 2011; Newman and Cho, } \\
\text { 2013) }[11,18]\end{array}$ \\
\hline \multicolumn{2}{|c|}{ I.R } & 0.65 & 0.34 & 0.67 & 1.59 & 0.79 & $0-5$ & $\begin{array}{c}\text { (BS EN 197-1, 2011; Newman and Cho, } \\
\text { 2013) }[11,18]\end{array}$ \\
\hline \multicolumn{2}{|c|}{ Alkaline Content \% } & 1.51 & 1.87 & 0.77 & 0.42 & 0.74 & $0.2-1.3$ & (Newman and Cho, 2013) [18] \\
\hline \multicolumn{2}{|c|}{ A/F ratio } & 1.43 & 1.52 & 0.74 & 1.68 & 1.70 & $\geq 0.64$ & (Newman and Cho, 2013) [18] \\
\hline \multicolumn{2}{|c|}{$C / S$ ratio } & 3.13 & 2.99 & 2.89 & 3.43 & 3.39 & $<2$ & (Newman and Cho, 2013) [18] \\
\hline \multirow{4}{*}{$\begin{array}{c}\text { Percentage } \\
\text { cement } \\
\text { composition }\end{array}$} & $\mathrm{C}_{3} \mathrm{~S}$ & 57.44 & 51.49 & 47.39 & 72.62 & 72.96 & $45-65$ & (Newman and Cho, 2013) [18] \\
\hline & $\mathrm{C}_{2} \mathrm{~S}$ & 12.94 & 21.36 & 25.85 & -3.31 & -0.51 & $10-30$ & (Newman and Cho, 2013) [18] \\
\hline & $\mathrm{C}_{3} \mathrm{~A}$ & 6.47 & 7.34 & 1.52 & 7.95 & 8.23 & $5-12$ & (Newman and Cho, 2013) [18] \\
\hline & $\mathrm{C}_{4} \mathrm{AF}$ & 9.34 & 9.52 & 16.61 & 8.80 & 8.89 & $6-12$ & (Newman and Cho, 2013) [18] \\
\hline \multirow{3}{*}{ Basic ratios } & LSF & 0.99 & 0.94 & 0.91 & 1.06 & 1.05 & $95-97$ & (Newman and Cho, 2013) [18] \\
\hline & SR & 2.63 & 2.66 & 2.26 & 2.32 & 2.41 & $2.4-2.6$ & (Newman and Cho, 2013) [18] \\
\hline & AR & 1.44 & 1.52 & 0.74 & 1.68 & 1.70 & $1.5-1.8$ & (Newman and Cho, 2013) [18] \\
\hline
\end{tabular}

The effects of IR are similar to the ones of LOI but they have been satisfactory in all the samples. The SR and $\mathrm{AR}$ are ratios used to optimize the cement production process and not the performance but this study has only examined these ratios as a glance-assessment of the presence of silica and alumina respectively.

\section{III.4. Microstructural Characterization of Cement Pastes}

Another way of assessing the characteristics of cement beyond what other physical, mechanical and chemical properties can reveal is the study of its micro structure.

These microstructural studies reveal the in-place particle distribution, the compositional distribution and the particle packing (in-place micro particle spaces or voids). Scanning Electron Microscope has been used in this research in order to investigate the microstructural characterization of the different brands of cement tested.

Fig. 2(a) is a $100 \mu \mathrm{m}$ view of SEM image of sample from brand $\mathrm{C} 1$. It shows the distribution of white and various levels of dark and grey shades. The white spots show the Ferrite $\left(\mathrm{Fe}^{+}\right)$and or Aluminate $\left(\mathrm{Al}^{+}\right)$present in $\mathrm{C}_{3} \mathrm{~A}$ or $\mathrm{C}_{4} \mathrm{AF}$, the light grey shade spots show the alites $\left(\mathrm{C}_{3} \mathrm{~S}\right)$ while the dark grey shade ones show the belites $\left(\mathrm{C}_{2} \mathrm{~S}\right)$ and the black ones show inter-particle or void spaces [20]. From Fig. 2(a), it can be inferred generally that the particles are mostly irregularly shaped; it is dominated by alites with fewer spots of belite and void spaces making the various particles distinct, separate and easily identifiable. Fig. 2(b) shows more visible Ferrites or Aluminates compared to Fig. 2(a). In addition, the various compositional particles are uniformly spread indicating that it is isotropic. Fig. 2(b) is a $20 \mu \mathrm{m}$ view of the circled portion of Fig. 2(a). It reveals greater details than in Fig. 2(a) by showing more white spots of Ferrite that have not been initially clearly visible in Fig. 2(a).
Figs. 2 seem to reflect the compositional distribution of brand $\mathrm{C} 1$ in Table II thereby further authenticating and complementing both results. Fig. 3(a) reveals that there are less alites, more belites, more Ferrites or Aluminates, greater pores and larger particle sizes than Fig. 2(a).

These accretions are the result of less light grey spots (alites), greater dark grey spots (belites), more visible white spots (ferrites and aluminates), greater black spots (particle spaces) and larger particle sizes than the one observed in Fig. 2(a). These characteristics are also confirmed when the results are compared with Table II.

Fig. 3(a) also reveals that the particles are irregularly shaped and isotropic. Fig. 3(b) is an upward magnification of a part of Fig. 3(a). They both portray the same. From the microstructural view point alone, Figs. 2 and 3 reveal that brand $\mathrm{C} 1$ might perform better than brand $\mathrm{C} 2$ in terms of early strength development but chemically, C2 is richer in combined calcium silicate than in C1 (Table II) thereby also having a tendency to perform better than $\mathrm{C} 1$ in terms of later strength development. However, from Fig. 1, it can be seen that $\mathrm{C} 1$ performs better than $\mathrm{C} 2$ suggesting that the influence of the microstructural size and spacing subsists despite the fact that the chemical composition of $\mathrm{C} 2$ favours greater strength development than $\mathrm{C} 1$. This shows that the strength enhancement should be developed both from the chemical composition and the microstructure of cements. The spread and the occurrence of the compositional microstructural particles also seem complementary to the chemical results shown in Table II.

Figs. 4 reveal more dark-grey shades and lesser lighter grey shades than all other cement microstructures indicating greater presence of $\mathrm{C}_{2} \mathrm{~S}$ (belite) than the other cement brands and also lesser $\mathrm{C}_{3} \mathrm{~S}$ (alite). This complements the findings in Table II with brand $\mathrm{C} 3$ possessing the highest percentage of belite composition compared with other cement brands. 


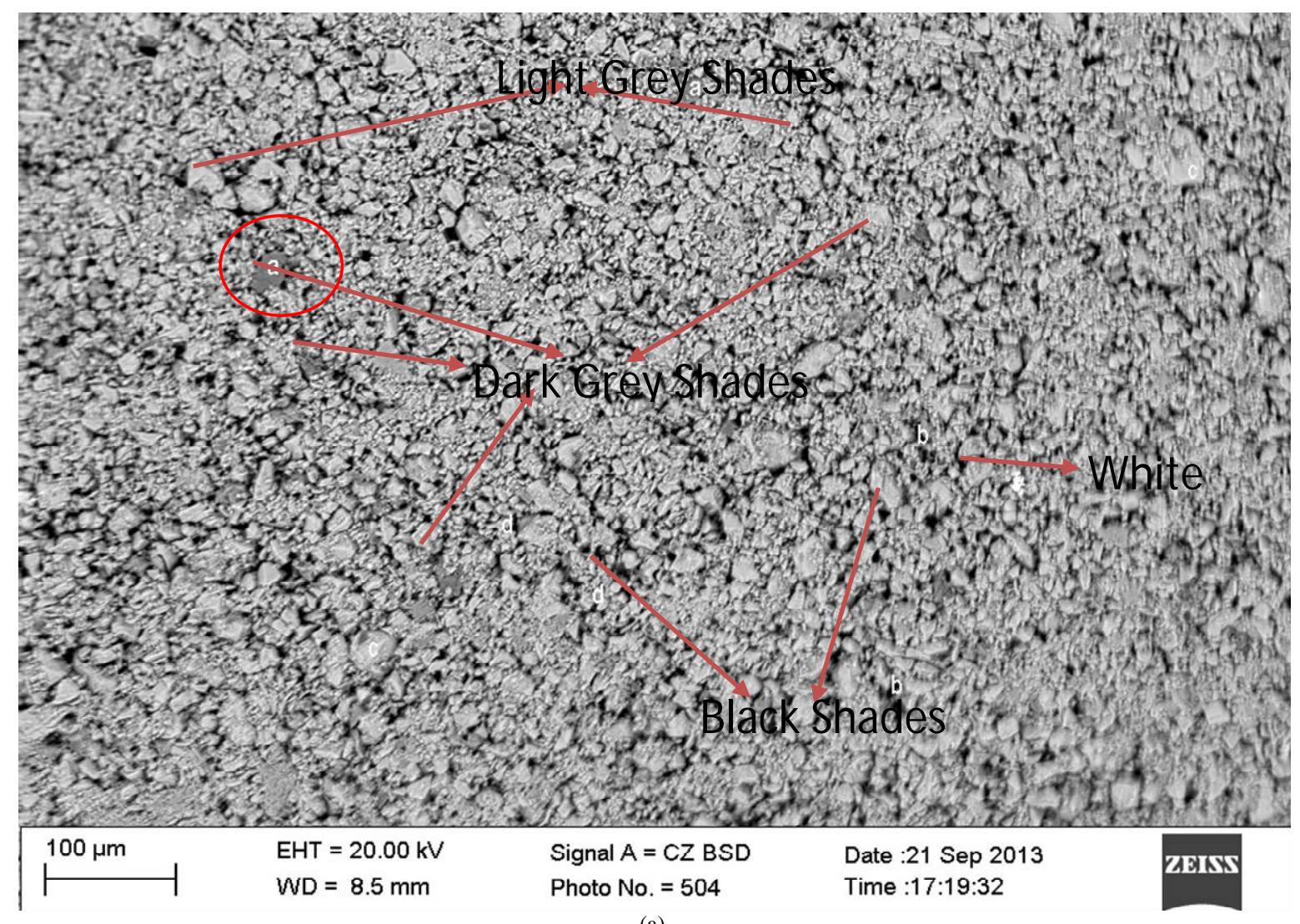

(a)

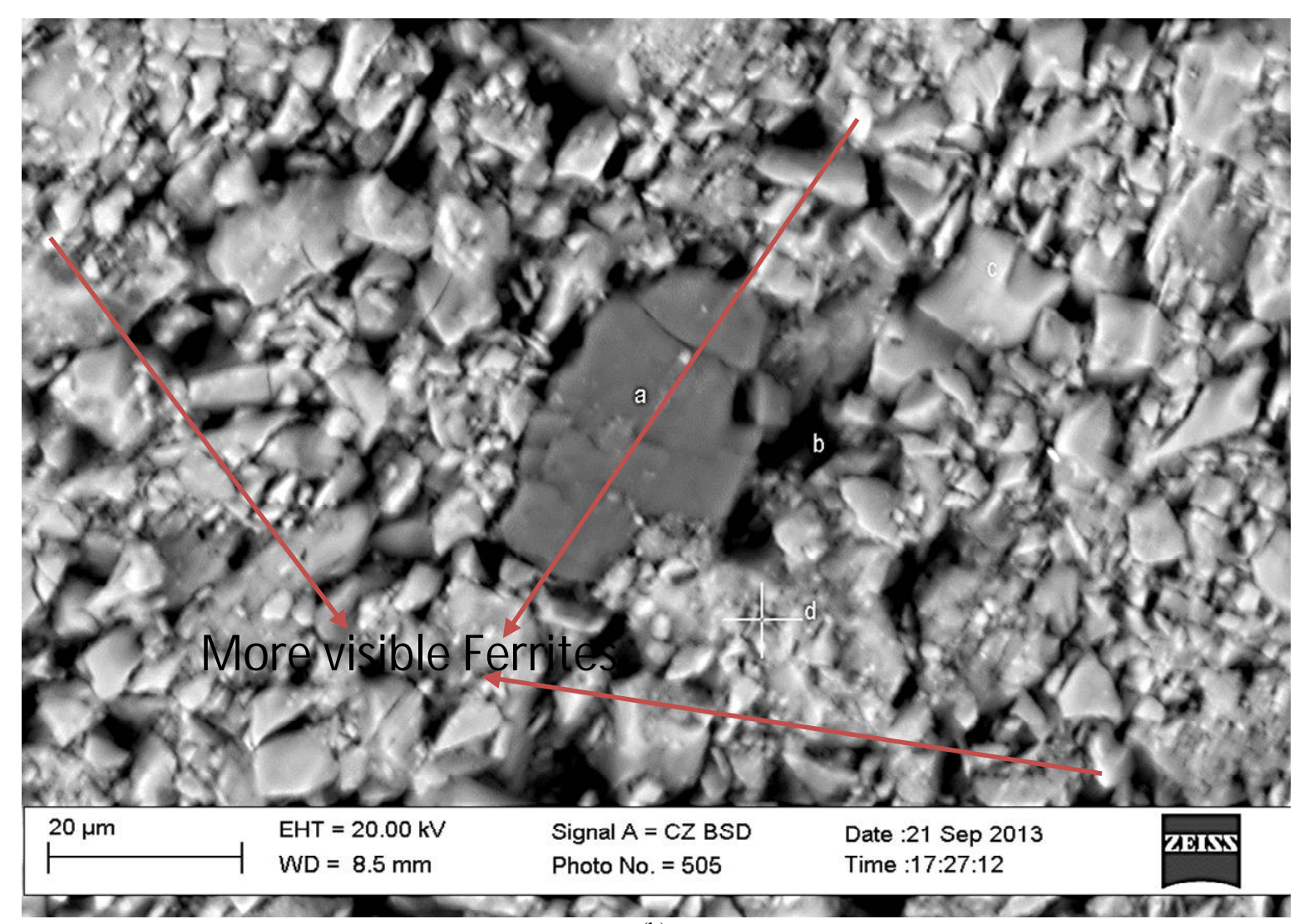

(b)

Figs. 2. Microstructure of Sample from Cement Brand C1 


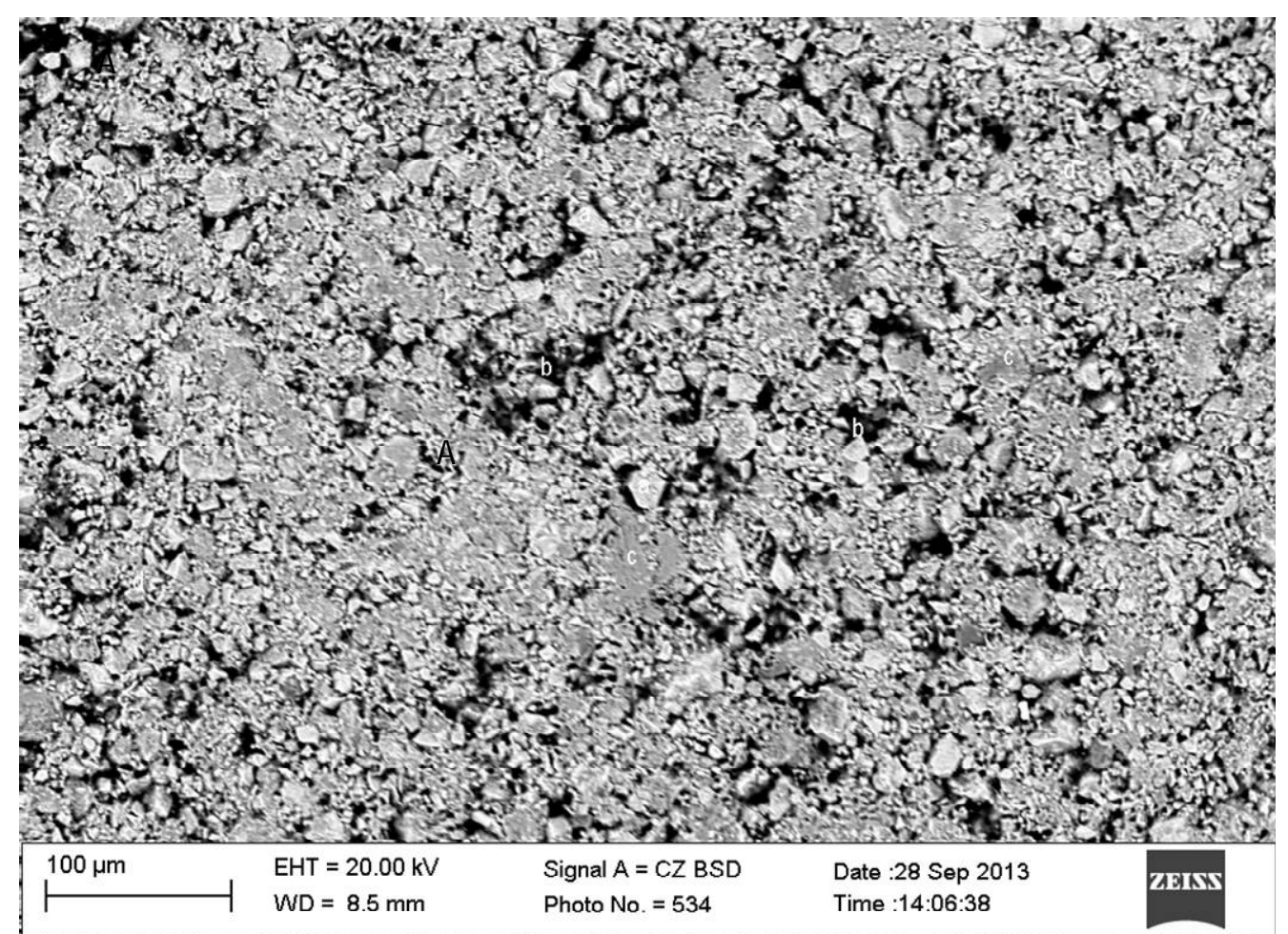

(a)

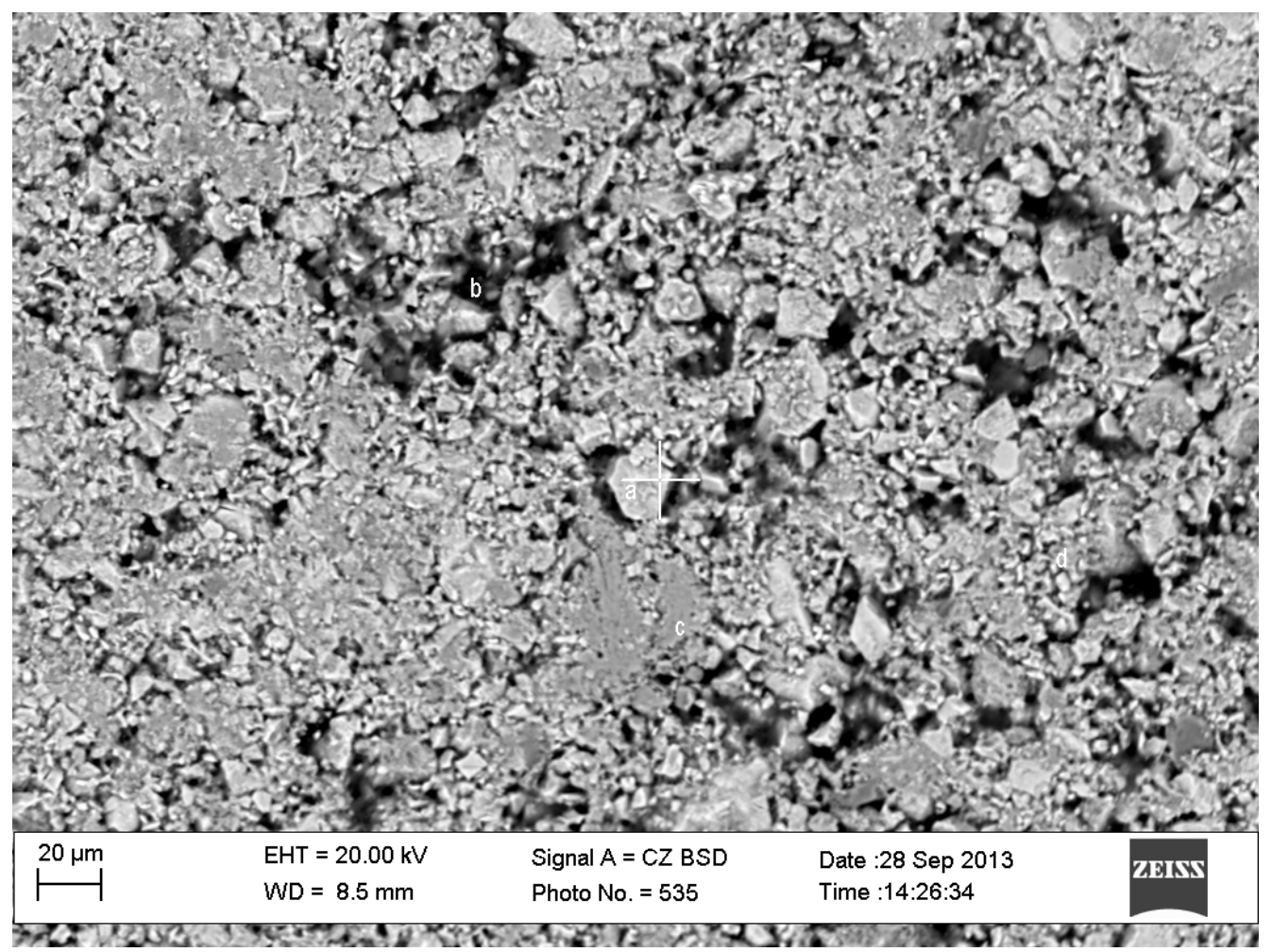

(b)

Figs. 3. Microstructure of Sample from Cement Brand C2

Cement brand $\mathrm{C} 3$ as revealed in Figs. 4 has got smaller particle sizes than other brands and they are more closely packed together evidenced by smaller black shades (smaller inter-particle spacing). It has even compositional spread (isotropic) though the particles are irregularly shaped and uneven sizes. The smaller particle sizes that are more closely packed together indicate quicker hydration by shorter setting times complementing the findings in Table I and earlier strength development complementing Fig. 1 with brand C3 possessing the shortest settings times and higher earlier strength development respectively compared with 
other cement brands. Fig. 5(a) reveals fewer dark grey spots indicating lesser belite which is complementary and consistent with findings in Table II. The particles are irregularly shaped, not uniformly sized and somehow homogenously dispersed. This shows earlier strength development due to greater presence of alite with fewer belite. In Fig. 5(b), the white spots are more clear and well dispersed in the micro structure signifying the presence of the Ferrites and aluminates which are also essential components of cements. When compared with
Figs. 4, C4 has got larger and greater inter-particle spaces with greater dispersion which could probably account for the reason why brand $\mathrm{C} 3$ has better strength characteristic than C4.Fig. 6 shows similar features like in Figs. 5 except that the particles are coarser and shows lesser particle size uniformity. When viewed from the microstructural point alone, brand C5 will most likely have a performance similar to brand $\mathrm{C} 4$ except that it might be less reactive due to the coarser nature of the particles.

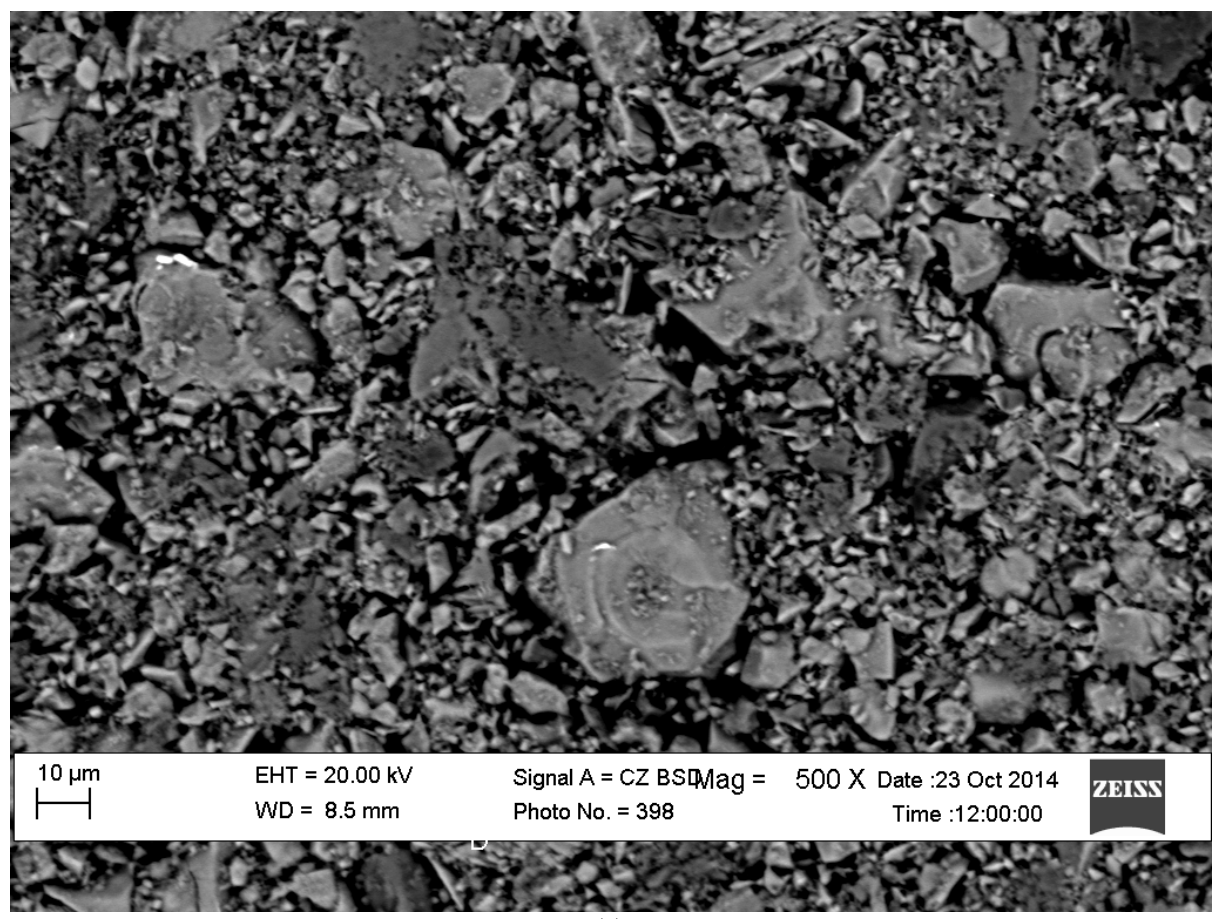

(a)

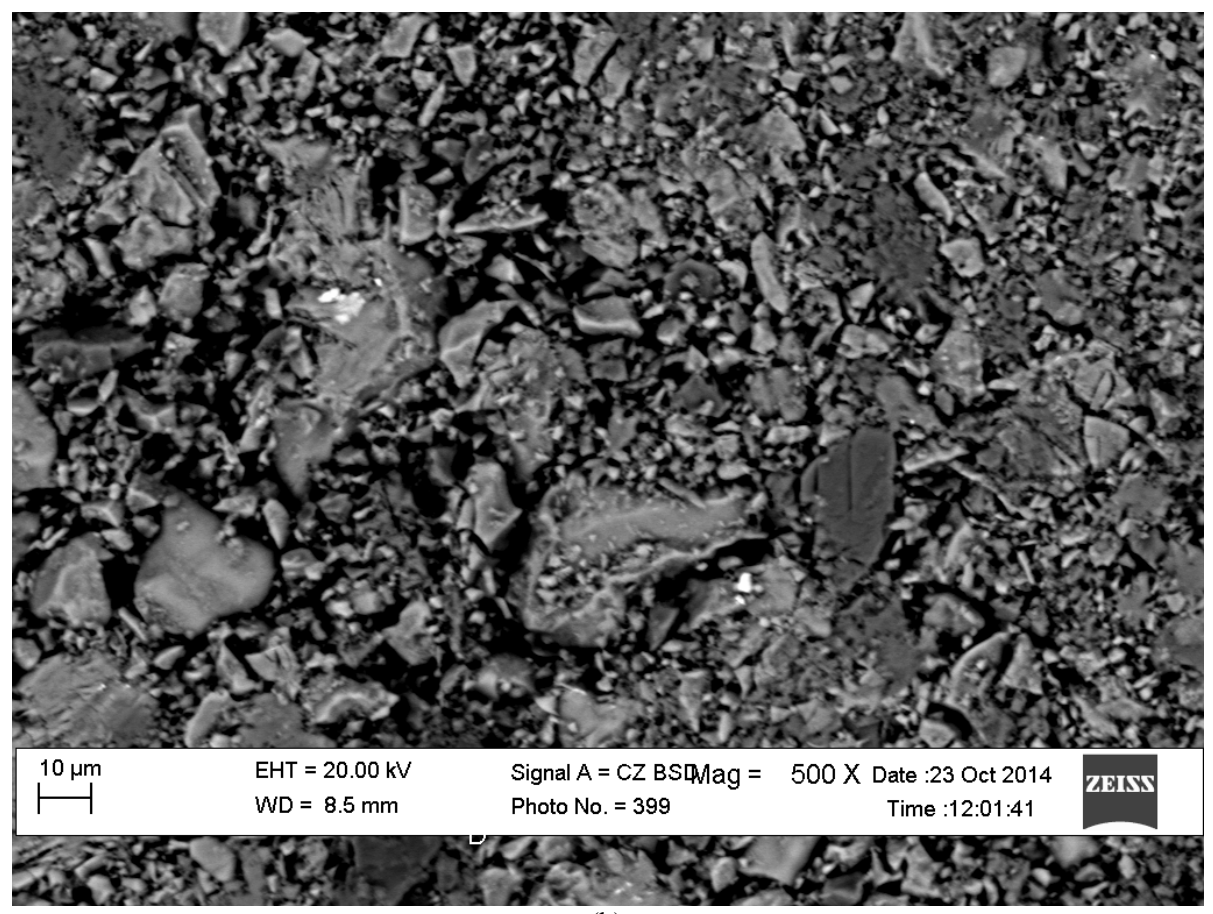

(b)

Figs. 4. Microstructure of Sample from Cement Brand C3 


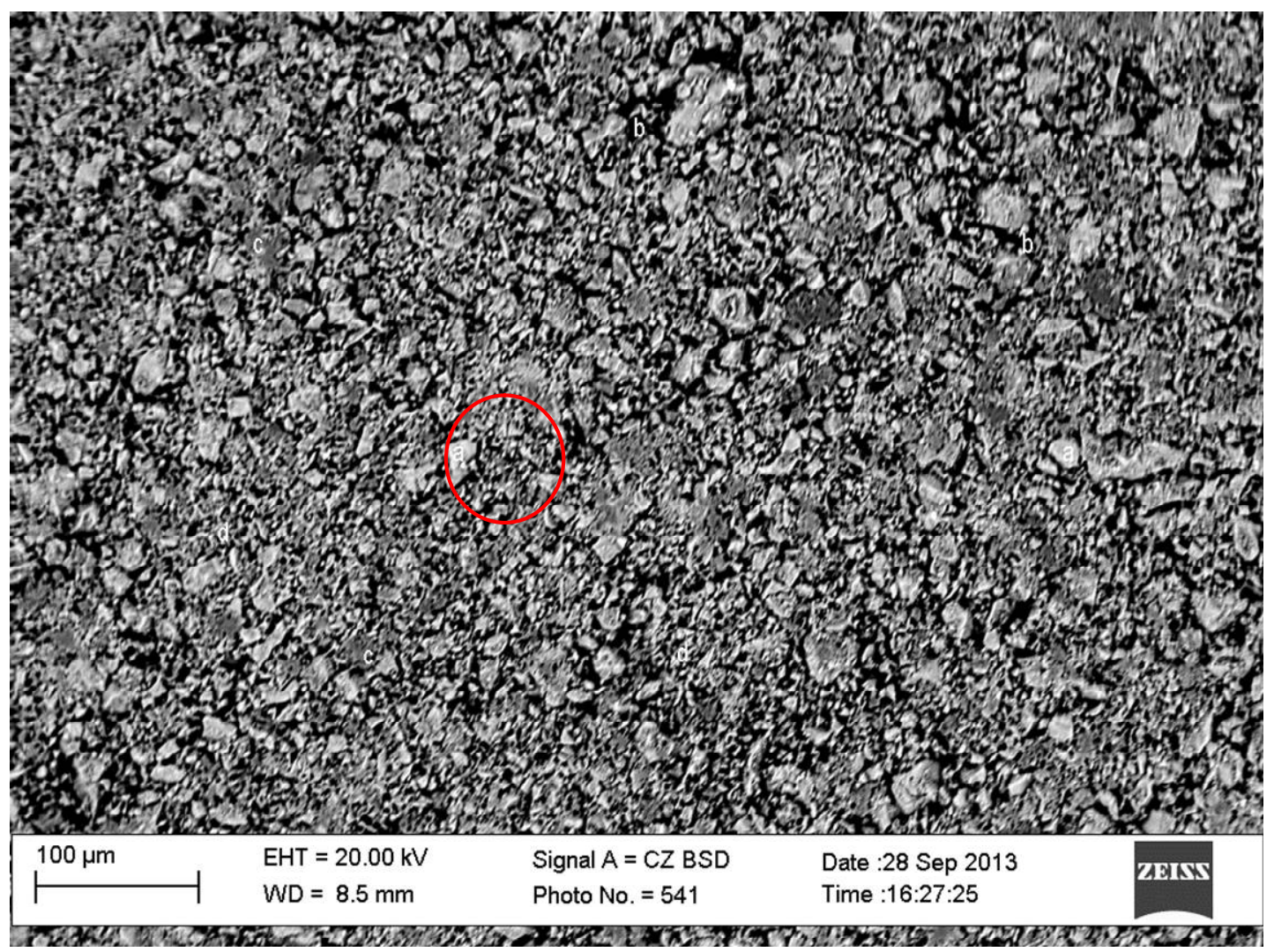

(a)

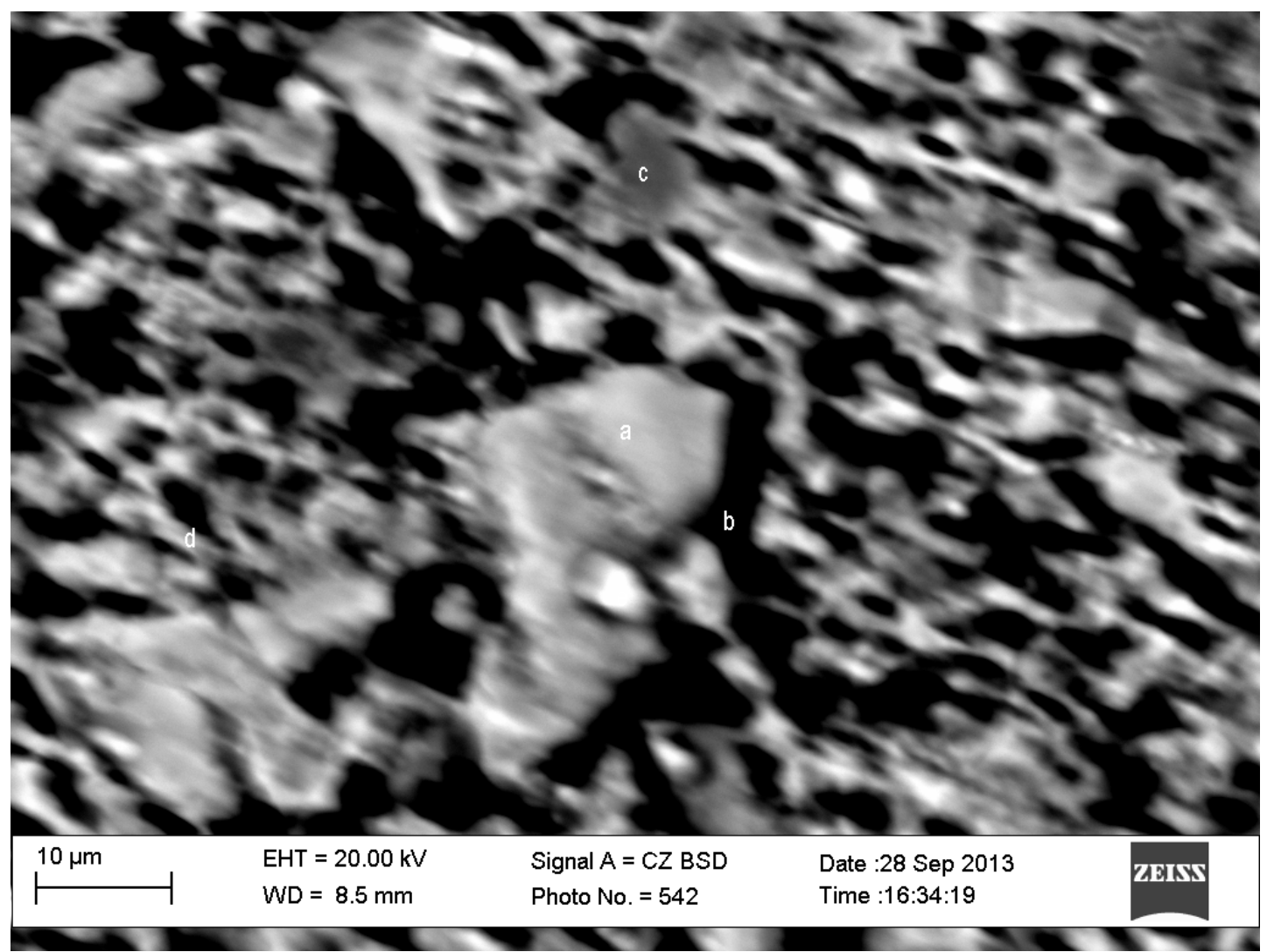

(b)

Figs. 5. Microstructure of Sample from Cement Brand C4 


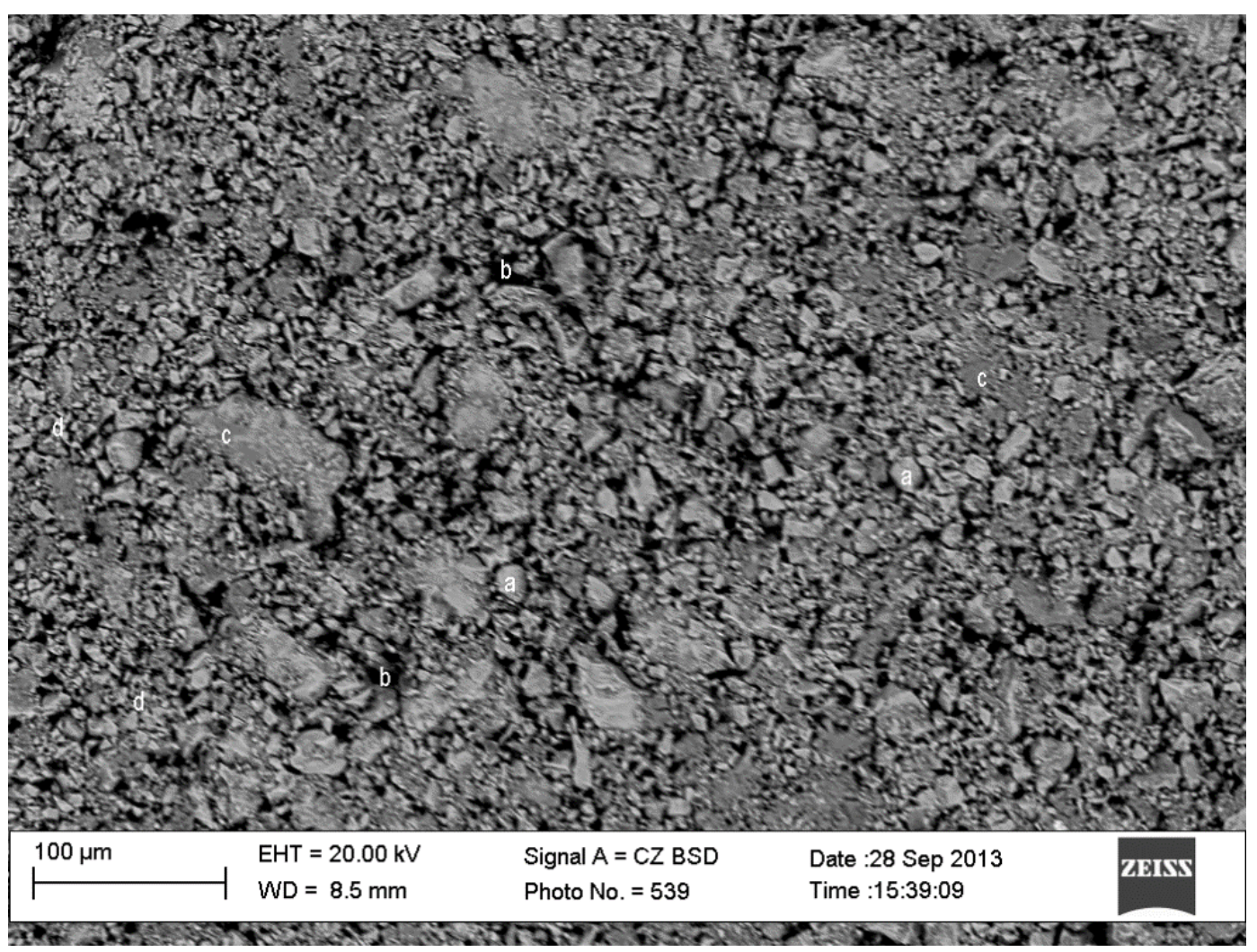

Fig. 6. Microstructure of Sample from Cement Brand C5

\section{III.5. Performance Evaluation of the Cements in Concrete}

In this section, three hundred and seventy-five (375) $100 \mathrm{~mm}$ concrete cubes have been cast with all the materials in this study to evaluate their performance in concrete. Using the principle of factorial experimental design, each one of the five brands of cement has been used to cast specimens incorporating all combinations of five fine aggregate and five coarse aggregate sources in three replicates per combination totaling to seventy-five samples per cement and three hundred and seventy-five for the five cements. The cube strengths as obtained from the compression crushing tests with $\mathrm{C} 1-\mathrm{C} 5$ representing the five cements being investigated and as described in the methods have been analyzed with the analysis of variance (ANOVA) which studied average values from different perspectives and show the level of significance of the various cements being investigated on the concrete strength. The strength has been the independent variable and the cements have been part of the dependent variable. Table III shows the significance level of the dependent variable, cement. From Table III, it is clear that cement had a significant effect on the strength values, indicating cement as a major determinant on the strength of the concrete samples produced as their significance level has been below 0.05. All the other combinations with cement have no significant effects on strength as their significance was above 0.05. As shown in Fig. 7, in order of 28-day strength performance, cement brand $\mathrm{C} 3$ has performed the best with a mean strength of $24.25 \mathrm{MPa}, \mathrm{C} 4$ with $23.59 \mathrm{MPa}, \mathrm{C} 5$ with $20.84 \mathrm{MPa}, \mathrm{C} 1$ with $19.95 \mathrm{MPa}$ and C2 19.64 MPa. This justifies the significance of cement on the compressive strengths from Table III. C1 and C2 have produced concrete of mean strengths below the recommended target strength of over $20 \mathrm{MPa}$. This confirms the results obtained in Fig. 1. The ranking from the best performing cement brand in Fig. 1 is same as in their performance in concrete as shown in Fig. 7. The actual means of cement in Fig. 7 complements the estimated marginal means in Fig. 7. The standard deviation of the cements strengths in Table III approximately $2.13 \mathrm{MPa}$ which makes the contribution of cements in the concrete the most significant because it should not exceed $1 \mathrm{MPa}(5 \%$ of the target strength of $20 \mathrm{MPa}$ ).

TABLE III

SigNIFICANCE LEVEL OF CEMENT AS DEPENDENT VARIABLES

\begin{tabular}{|c|c|c|c|c|c|}
\hline \multicolumn{6}{|c|}{ Dependent Variable: Compressive Strength } \\
\hline Source & $\begin{array}{l}\text { Type III } \\
\text { Sum of } \\
\text { Squares }\end{array}$ & df & $\begin{array}{l}\text { Mean } \\
\text { Square }\end{array}$ & $\mathrm{F}$ & Sig. \\
\hline Corrected Model & $2558.563^{\mathrm{a}}$ & 124 & 20.634 & 4.364 & .000 \\
\hline Intercept & 175831.130 & 1 & \multicolumn{2}{|c|}{175831.13037186 .112} & .000 \\
\hline cement & 1358.219 & 4 & 339.555 & 71.812 & .000 \\
\hline cement $*$ sand & 38.951 & 16 & 2.434 & .515 & .938 \\
\hline \multirow{2}{*}{$\begin{array}{c}\text { cement } * \text { gravel } \\
\text { cement } * \text { sand } * \\
\text { gravel }\end{array}$} & 95.844 & 16 & 5.990 & 1.267 & .219 \\
\hline & 128.904 & 64 & 2.014 & .426 & 1.000 \\
\hline Error & 1182.102 & 250 & \multirow{2}{*}{\multicolumn{2}{|c|}{4.728}} & \\
\hline Total & 179571.794 & 375 & & & \\
\hline Corrected Total & 3740.665 & 374 & & & \\
\hline Standard dev & $\begin{array}{l}\text { ation of the } \\
\text { approxin }\end{array}$ & $\begin{array}{l}\text { rengtl } \\
\text { ately }\end{array}$ & $\begin{array}{l}\text { of ceme } \\
13 \mathrm{MPa}\end{array}$ & concre & \\
\hline
\end{tabular}




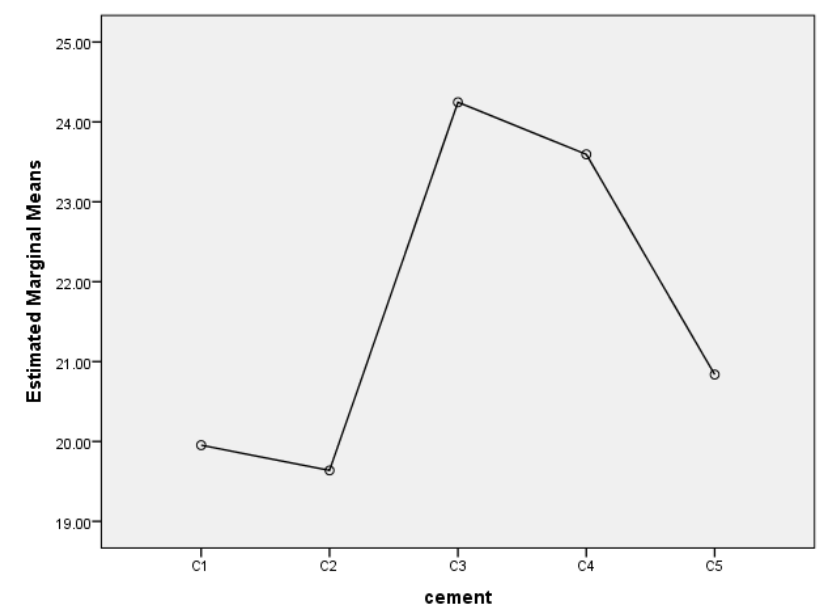

Fig. 7. Estimated Marginal Means of the Compressive Strengths of Cement being investigated (MPa)

\section{Conclusion and Recommendation}

\section{IV.1. Conclusion}

The cement type and class has not been displayed on the bags of $\mathrm{C} 1$ and $\mathrm{C} 2$ which is a requirement in NIS444 (2003) but other brands have complied in this regard. All cement brands have complied with the standard setting times limits to [17] and [11]. The best 28-day mortar cement strength has been developed by brand $\mathrm{C} 3$ with strength of $45.06 \mathrm{MPa}$. Brands C3, C4 and C5 have satisfied the standard strengths recommended by [17] and [11] but C1 and C2 have not. Only the cements brands that had strength class and type label satisfied the recommended standards. C3 has showed high earlier strength hence justifying the rapid hardening label on bag. All the oxides composition of all the cement brands have been within the limits specified by [17] and [11] except for the alkaline percentages for $\mathrm{C} 1$ and $\mathrm{C} 2$ making them more susceptible to Alkaline Silica Reaction (ASR) that could compromise long-term strength. All the cement brands have complied with the cement compositions in [17] and [11] except for the tricalcium silicate $\left(\mathrm{C}_{3} \mathrm{~S}\right)$ and dicalcium silicate $\left(\mathrm{C}_{2} \mathrm{~S}\right)$ of samples $\mathrm{C} 4$ and C5.C4 and C5 may have showed earlier strength development than the others because of higher tricalcium silicate $\left(\mathrm{C}_{3} \mathrm{~S}\right)$ contents.C3, C4 and $\mathrm{C} 5$ had higher percentages on Loss On Ignition (LOI) beyond [17] and [11] limits. From the cements microstructural viewpoint, the visible alites, belites, ferrites, and aluminates from the SEM images complemented the chemical composition and added details of general irregularly shaped and non-uniform particle sizes, which could be improved upon to optimize better strength characteristics.

From Table III, it is clear that the cement, the fine and the coarse aggregates (sand and gravel) alone had significant effect and so did the interaction between the fine and coarse aggregates as their significance has been below 0.05 . All the other combinations had no significant effects as their significance has been above 0.05. From these conclusions, focus for further analysis will be on the cement fine and coarse aggregates alone and the finecoarse aggregate interactions. As shown in Fig. 7, in order of 28-day strength performance, cement brand C3 performed most with a mean strength of $24.25 \mathrm{MPa}, \mathrm{C} 4$ with $23.59 \mathrm{MPa}, \mathrm{C} 5$ with $20.84 \mathrm{MPa}, \mathrm{C} 1$ with $19.95 \mathrm{MPa}$ and $\mathrm{C} 219.64 \mathrm{MPa}$. This justifies the significance of cement on the compressive strengths from Table III. C1 and $\mathrm{C} 2$ produced concrete of mean strengths below the recommended target strength of over $20 \mathrm{MPa}$. This confirms the results obtained in Fig. 1. The ranking from the best performing cement brand in Fig. 1 is same as in their performance in concrete as shown in Fig. 7.

\section{IV.2. Recommendation}

The following recommendations have been made from the conclusion. It should be ensured that all strength classes and types of cements are labelled on the various cement bags. All erring brands in this regard should be made to comply as they possess the least strength properties in all the study cement brands. Much should be done to improve the Loss On Ignition (LOI) of Nigerian cements as this could enhance their strength characteristics. The significant concrete strength material contribution is mainly due to cement variation. The contribution of aggregates is of smaller significance hence, improving cement quality will generally improve the state of the Nigerian concrete structures. Any cement brand(s) whose strength labels were absent should be utilized cautiously in structural concrete applications.

Pending when the Nigerian regulatory institution (Standard Organization of Nigeria, SON) on cement could compel the cement brands to fully comply to the existing standards, the 42.5 strength class should be used as a 32.5 class because all the 42.5 strength class cements have failed to meet the cement-strength of $42.5 \mathrm{MPa}$ but they have all been above $32.5 \mathrm{MPa}$ marl for 32.5 cement class.

\section{References}

[1] Ede, A. N. (2010). Building Collapse in Nigeria: The Trend of Casualties in the Last Decade (2000 -2010). International Journal of Civil and Environmental Engineering (IJCEE-IJENS). 10(6), 32-41.

[2] National Institute of Building Sciences Building Seismic Safety Council, (2010). Earthquake-Resistant Design Concepts, an Introduction to the NEHRP Recommended Seismic Provisions for New Buildings and other Structures. Federal Emergency Management Authority (FEMA) P-74 of the U. S. Department of Homeland Security.

[3] Joshua, O., Olusola, K.O., Ayegba, C. and Yusuf, A. I. (2013). Assessment of the Quality of Steel Reinforcement Bars Available in Nigerian Market. Conference Proceedings of the Architectural Engineering Institute (AEI) of the American Society of Civil Engineers (ASCE). Theme: Building Solutions for Architectural Engineering. Pennsylvania, USA. 295 - 304.

[4] Joshua, O., Olusola, K. O., Oyeyemi, K. D., Ogunde, A. O., Amusan, L. M., Nduka, D. O., \&Abuka-Joshua, J. (2018). Data of the properties of rebar steel brands in Lagos, Nigerian market used in reinforced concrete applications. Data in brief, 17, 14281431.

[5] Joshua, O., Amusan, L. M., Olusola, K. O., Ogunde, A., Ede, A. N., \& Tunji-Olayeni, P. F. (2017). Assessment of the Utilization 
of Different Strength Classes of Cement in Building Constructions in Lagos, Nigeria. International Journal of Civil Engineering and Technology (IJCIET), 8(9), 1221-1233.

[6] Olusola, K. O and Joshua, O. (2012). Effects of Nitric Acid Concentration on the Compressive Strength of Laterised Concrete. Civil and Environmental Research. 2(10), 48-57.

[7] Oke, A. and Abiola-Falemu, J. (2009). Relationship between Building Collapse and Poor Quality of Materials and Workmanship in Nigeria. Proceedings of the Royal Institute of Chartered Surveyors (RICS) COBRA Research Conference, University of Cape Town, 10-11th September 2009. 873-884.

[8] Ogunsemi, D. R. (2002). Cost control and quality standard of building projects in Ogunsemi, D. R. (Ed.). Building Collapse: Causes, prevention and remedies. The Nigerian Institute of Building, Ondo State. 88-94.

[9] BS EN 12620:2002 +A1 (2008). Aggregates for Concrete. British Standard Institute. London.

[10] BS EN 196-1 (2005). Methods of Testing Cement. Determination of Strength. British. Standard Institute. London.

[11] BS EN 197-1 (2011). Cement Part 1: Composition, Specifications and Conformity Criteria for Common Cements. British Standard Institute. London.

[12] ASTM C150/C150M-18, Standard Specification for Portland Cement, ASTM International, West Conshohocken, PA, 2018, www.astm.org

[13] BS EN 196-3 (2016). Methods of Testing Cement. Determination of Setting Times and Soundness. British Standard Institute. London.

[14] BS EN 206:2013+A1 (2016). Cement-Specification, Performance, Production and Conformity. British Standard Institute, London.

[15] BS 8500-1:2015+A1 (2016). Method of Specifying and Guidance for the Specifier. British Standard Institute. London.

[16] 8500-2:2015+A1 (2016). Specification for Constituent Materials and Concrete. British Standard Institute. London.

[17] NIS 444-1 (2003). Composition, specifications and conformity criteria for common cements. Nigeria Industrial Standard (NIS) in the Standard Organization of Nigeria (SON).

[18] Newman, J. and Choo, B. S. (2003). Advanced Concrete Technology Constituent Materials. Butterworth-Heinemann. An imprint of Elsevier, Linacre House, Jordan Hill, Oxford OX2 8DP. USA.

[19] Neville, A. M. and Brook, J. J. (2010). Concrete Technology. $2^{\text {nd }}$ ed. Pearson Education Limited. Edinburgh Gate Harlow Essex CM20 2JE England.

[20] Winter, N. B. (2012). Scanning Electron Microscopy of Cement and Concrete. WHD, Microanalysis Consultants, Woodbridge, Suffolk. U.S.A.

[21] Harapin, A., Ostojic Skomrlj, N., Cubela, D., A Case Study on Construction Technology for the Reinforced Concrete Dome of the Višnjik Sports Hall, Zadar, Croatia, (2018) International Review of Civil Engineering (IRECE), 9 (4), pp. 131-140. doi:https://doi.org/10.15866/irece.v9i4.14882

[22] Benjabrou, M., Zeggwagh, G., Gueraoui, K., Sammouda, M., Bendada, A., Comparative Study of the Behavior of Metallic and Reinforced Concrete Structures Under the Effect of Tsunami Waves, (2018) International Review of Civil Engineering (IRECE), 9 (6), pp. 248-255. doi:https://doi.org/10.15866/irece.v9i6.15374

[23] Sapountzakis, E., An Improved Model for the Analysis of Plates Stiffened by Parallel Beams Including Creep and Shrinkage Effects: Application to Concrete or to Composite Steel-Concrete Structures, (2018) International Journal on Engineering Applications (IREA), 6 (2), pp. 57-70. doi:https://doi.org/10.15866/irea.v6i2.15377

[24] Benjabrou, M., Zeggwagh, G., Gueraoui, K., Sammouda, M., Driouich, M., Evaluation of Seismic Vulnerability of Existing Reinforced Concrete Structure by Non-Iterative Spectral Method Using Pushover Analysis with Interpretation of Fragility Curves by RISK UE, (2017) International Review of Civil Engineering (IRECE), 8 (4), pp. 177-186. doi:https://doi.org/10.15866/irece.v8i4.11892

[25] Maryoto, A., Ay Lie, H., Gunawan Wariyatno, N., The Live Load Capacity of Rectangular Precast Reinforced Concrete Stick Plates, (2018) International Review of Civil Engineering (IRECE), 9 (5), pp. 174-180.

doi:https://doi.org/10.15866/irece.v9i5.15542

\section{Authors' information}

${ }^{1}$ Department of Building Technology, Covenant University, Ota, Nigeria.

${ }^{2}$ Department of Building, Obafemi Awolowo University, Ile-Ife, Nigeria.

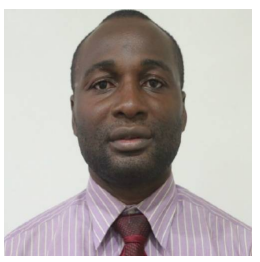

Opeyemi Joshua (Ph.D Building Structures) is a Senior Lecturer in the Department of Building Technology, Covenant University. His research interest is in the field of improving concrete strength/durability with more emphasis on development of innovative, optimized, indigenous, affordable, green and sustainable construction material in building applications. He has considerably researched on cement, pozzolans/pozzolanicprocess, supplementary cementitious materials, and is currently researching on the development of a fully cement-alternative binder. He is a registered Building Professional with the Council of Registered Builders of Nigeria (CORBON).

E-mail: ope.joshua@covenantuniversity.edu.ng

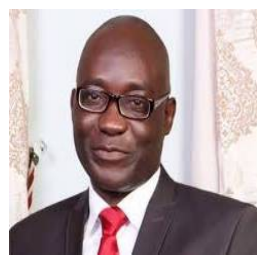

Kolapo Olubunmi Olusola (Ph.D Building Structures) is a Professor of Building in Obafemi Awolowo University, Ile-Ife. He has significantly researched in Laterised concrete, concrete durability in different environments, development of innovative, optimized, indigenous, affordable, green and sustainable construction material. $\mathrm{He}$ is a registered Building Professional with the Council Of Registered Builders of Nigeria (CORBON) and is currently into State Administration.

E-mail: kolaolusola@yahoo.co.uk

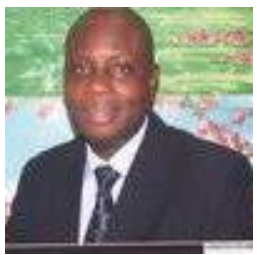

Olabosipo Fagbenle (Ph.D Construction Management) is a professor of Building and Construction Management in Covenant University. He js a Professor of international repute as he has supervised and still supervising numerous $\mathrm{PhDs}$ and extensively researched in in the field of construction management, improved project's TQC (Time Quality and Cost), computing and Information Technology in Building, and many other areas. He has been engaged as external examiners in Universities globally. He is a registered Building Professional with the Council Of Registered Builders of Nigeria (CORBON)

E-mail: olabosipo.fagbenle@ covenantuniversity.edu.ng

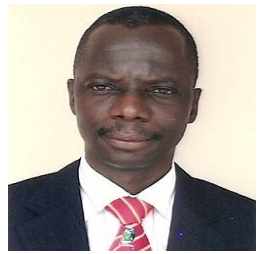

Ayodeji Olubunmi Ogunde obtained his $\mathrm{PhD}$ in Construction Management at Covenant University, Canaanland, Ogun State, Nigeria in 2013. He is registered with Nigerian Institute of Building (NIOB). He is licensed to practice as Registered Builder by the Council of Registered Builders of Nigeria (CORBON). He is academically sound and professionally competent with robust professional experience spanning over three (3) decades in the construction industry at the managerial level. Before he joined the academia in 2006, he was deeply involved in the construction of high-profile edifices and consultant in many Landmark projects across the nation. He is also knowledgeable in the construction of prefabricated acrylic fiberglass swimming pools. $\mathrm{He}$ was also involved in the drafting of National Policy on Blue Print on Mass Housing in Nigeria (2018-2050). He has a vast number of publications in both local and high impact international journals.

His special interests are majorly innovations in the areas of Construction Management, Building Services, development of new materials and constructional methods towards innovation of the most effective and efficient building in the whole world. He is currently a 
Lecturer in the Department of Building, Covenant University, Canaanland, Ogun State, Nigeria

E-mail: ayodeji.ogunde@covenantuniversity.edu.ng

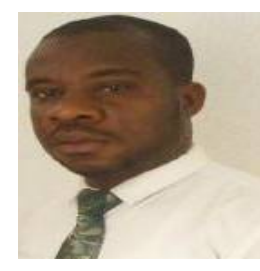

Mr David Nduka is a Faculty member at the Department of Building Technology, Covenant University, Nigeria. He holds BSc in Building and MSc in Construction Technology and currently a PhD hopeful of Building Structures. Bldr. David is a corporate member of Nigerian Institute of Building (NIOB) and a certified member of Council of Registered Builders of Nigeria (CORBON). His research interest includes Construction Technology, Built Environment Sustainability, Green Building and Building Material Science

E-mail: david.nduka@ covenantuniversity.edu.ng 